\title{
What Is New in Ophthalmic Research
}

\section{Two Different Pathways of Cyclic GMP Synthesis in Human Retinal Pigment Epithelium Cells \\ Diederen et al., Maastricht, The Netherlands \\ Ophthalmic Res 2008;40:227-234}

Cyclic GMP plays an important role in the function of retinal pigment epithelium (RPE) cells. In this study, we showed the simultaneous presence of the inducible isoform of nitric oxide synthase (iNOS) and atrial natriuretic peptide (ANP) which suggests two different autocrine pathways of stimulating cGMP production in these cells. One possible explanation for the presence of two autocrine mechanisms both using cGMP as a second messenger could be the role of cGMP in the regulation of iNOS gene expression. It might be possible that cGMP keeps the expression of iNOS and the NPR-A receptor in an equilibrium state. This keeps ANP signaling in the RPE layer at a low level, but high enough to control iNOS expression. By controling the iNOS expression, the endogenous nitric oxide (NO) concentration can be kept at such a low level that the toxic properties of $\mathrm{NO}$ will not become a hazard to the retina.

\section{Optical Coherence Tomography: Fast versus Regular Scanning Speed in Diabetic Maculopathy \\ Ceklic et al., Sarajevo, RS Bosnia \\ Ophthalmic Res 2008;40:235-240}

The scanning speed is known to be important to avoid motion artifacts with optical coherence tomography (OCT). However, this may not be clinically relevant with the time domain Stratus OCT: in patients with diabetic macular edema, the absolute thickness measurements were not different between fast low-resolution and slow but high-resolution scanning. In addition, the fast lowresolution mode yielded only a minimal decrease in reproducibility. This implies that in clinical practice, both scanning modes can be interchanged and that the absolute measurements can be compared.

\author{
Retinal Degeneration in a Murine Model of Sandhoff \\ Disease \\ Sango et al., Tokyo, Japan \\ Ophthalmic Res 2008;40:241-248
}

The infantile forms of $\mathrm{G}_{\mathrm{M} 2}$ gangliosidoses are characterized by a macular cherry-red spot and progressive retinal degeneration. This is due to accumulation of $\mathrm{G}_{\mathrm{M} 2}$ ganglioside and related glycolipids. Sango et al. fully described the pathological features of retinas in a murine model of $\mathrm{G}_{\mathrm{M} 2}$ gangliosidosis (Sandhoff disease). The light and electron microscopy revealed ganglioside storage in the retinal neurons - especially retinal ganglion cells (RGC) and amacrine cells - and the retinal pigment epithelial (RPE) cells. In addition, the lectin histochemistry showed oligosaccharide storage in RGC and RPE cells of Sandhoff disease mice at 3 months of age. Some neurons appeared to undergo apoptotic changes in severely affected mice at 4 months of age. These findings suggest that neuronal and RPE cells are more vulnerable to the deficient ganglioside degradation than other retinal cells in Sandhoff disease mice. This study provides novel and useful concepts to better understand the process of retinal degeneration and develop effective treatments for $\mathrm{G}_{\mathrm{M} 2}$ gangliosidoses.

\section{How Useful Are Biopsies in Suspicious Pigmented Iris Tumors? \\ Schalenbourg et al., Lausanne, Switzerland \\ Ophthalmic Res 2008;40:267-272}

For suspicious pigmented iris tumors, a biopsy is indicated according to several authors. We compared the histopathological diagnosis of 10 consecutive specimens obtained since 1993 from patients with long-term follow-up and explored the utility of such a biopsy. Interestingly, 5 out of 10 biopsies had provided a falsely reassuring negative and 1 an inconclusive result. Coexistence of different clones of nevus and melanoma cells or dedifferentiation of a nevus into melanoma after the biopsy explained the disparity between histopathological and final diagnoses. Clinical outcome in these cases tended to be worse. Additionally, ultrasound biomicroscopy has increased confidence in periodic observation as a primary approach. In the management of lesions clinically evocative of iris melanoma, a biopsy has only a limited value.

Uwe Pleyer, Editor-in-Chief

\begin{tabular}{ll}
\hline KARGER & ( ) 2008 S. Karger AG, Basel \\
Fax +41613061234 & \\
$\begin{array}{l}\text { E-Mail karger@karger.ch } \\
\text { www.karger.com }\end{array}$ & $\begin{array}{l}\text { Accessible online at: } \\
\text { www.karger.com/ore }\end{array}$
\end{tabular}

